\title{
Factors affecting consumers' intention towards purchasing halal food in South Africa: a structural equation modelling
}

\author{
Abdalla M. Bashir, Abdullah Bayat, Samuel Oladipo Olutuase \& Zul Ariff Abdul Latiff
}

\begin{abstract}
This research study highlighted the factors that influence the intention of consumers to buy halal food products. In this study, the researchers have chosen to address the gap in the literature pertaining to non-South African consumers' purchase intention. Non-South Africans are foreign people who reside in South Africa including immigrants, workers, and students. Through utilising the theory of planned behaviour, this study aims to determine the attitudes, subjective norms, perceived behaviour control, and awareness of non-South African towards purchasing halal food products. This also attempts to identify the strongest factor that influences the purchasing intention of halal food by non-South African consumers. The sample of the study consisted of 230 non-South African consumers in Cape Town. Data were collected through self-administered questionnaires. Structural equation modelling (SEM) was used to identify the structural relationships among the constructs identified and to test the study hypotheses. The findings of this study indicate that there is a significant relationship between awareness and buying behaviour. Interestingly it found that only the attitude dimension of TPB had a significant relationship with purchase intention, whereas subjective norms and perceived behavioural control did not show a significant relationship with the consumer intention variable.
\end{abstract}

\section{Key Words}

Halal awareness; Intention; Buying behaviour; Halal food products; TPB; South Africa

\section{Introduction}

Food industries have become more concerned and sensitive about the manufacturing and sourcing of halal products. Halal products broadly receive acknowledgement as a scale for food safety and quality assurance (Majid, Abidin, Majid, \& Chik, 2015). Currently, the concern for consuming halal food products is not only prevailing among Muslim consumers, but also the halal awareness has extended to non-Muslims as well. Awareness of halal food is growing worldwide particularly in non-Muslim countries including South Africa. For this, there has been a greater awareness among hotels, guesthouses, and corporate venues and they have included halal menus. Additionally, the success of the halal food industry depends on the awareness of halal consumer (Mohamed, Shamsudin, \& Rezai, 2013). 
Trade in halal products is estimated at around US $\$ 150$ billion annually (Bamba, Talek, \& Kaba, 2017; Egan, 2002) and growing. According to the Holy Quran, a halal food product is a product that meets the requirements of halal according to Islamic law. Most foods and drinks are considered halal except that it has been obviously stated as non-halal (haram) or prohibited in the Holy Quran and the prophetic hadith. Therefore, Allah (SWT) has commanded His Messengers Muhammed (S.A.W), where He says: "O mankind! Eat of that which is lawful and good on the earth. .." (Al-Quran. Surah Al-Baqarah, Chapter II Verse 168). Halal food and beverages are described as anything that can be eaten or drunk and there is no lawful evidence about its prohibiting, as well as their ingredients are free from any prohibited or contaminated components (Said, Hassan, Musa, \& Rahman, 2014). Halal products are food being produced and consumed not only in countries that have high population of Muslims, but also in countries that have a low population of Muslims including South Africa, this makes halal products available worldwide (Hassan, 2013).

Trade of halal foods market is growing as one of the markets with tremendous potential in the world (Berry, 2008; Muhammad, Isa, \& Kifli, 2009; Shah Alam \& Mohamed Sayuti, 2011; Sungkar, Othman, \& Hussin, 2008), which makes a trade in halal products globally successful (Hassan, 2013). Research conducted by Halal Industry Development Corporation (2014) and Halal Research Council (2010) estimated that the global halal products market is valued at USD2.3 trillion (not including Islamic finance and banking), which means that halal industry is a lucrative trillion dollar business. Of this trade, the halal food and beverages representUSD1.4 trillion, with 67\% share of this market (The Halal Journal, 2010).

In addition, the demand for halal products and services has increased to US $\$ 655$ billion in 2010 from US $\$ 635$ billion in 2009 (Bernama, 2009). Halal food products are a concern for consumers mainly Muslims, because of its hygienic, cleanliness, animal welfare, and safety issues (Marzuki, Hall, \& Ballantine, 2012), and because it provides further assurances on food safety and quality (Nastasha, 2015; Teng, Siong, \&Mesbahi, 2013). This is so because there is a high demand for halal products in some non-Muslim countries for both Muslim and non-Muslim consumers (Berry, 2008). This is the case in South Africa, in which Muslims are a minority. Although Muslims being a minority in South Africa, it has a highly developed halal ecosystem. In South Africa, halal products are broadly available in local market (SalaamGateway.com, 2017). It also represents about 50\% of the total consumption of the productive sector in theAfrican continent (Bamba et al., 2017).

However, in South Africa, there are no formal statistics on halal food production or sales, but South African National Halaal Authority (SANHA) estimated that in 2012, 60\% of all food products were halal-certified (SalaamGateway.com, 2017). In addition, the Western Cape provincial government is researching and seriously considering the establishment of a halal agroprocessing food park in Cape Town (Hancock, 2015). Halal products are also growing in popularity due to the real awareness that halal products are healthier, safer and is produced using humane animal treatment (Teng et al., 2013). For these reasons, there is a need for researchers to investigate halal consumer intention and behaviour of Muslim and non-

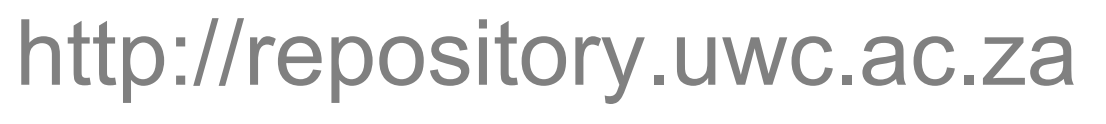


Muslim in South Africa. However, in this research study, we focus on resident non-South African Muslim and non-Muslim consumers' intention and behaviour in the Western Cape.In South Africa, the awareness of halal amongst Muslims and non-Muslims has not yet investigated by South African scholars. In addition, the intention of consumers towards buying halal food has also not been investigated thus far, there is also another category of halal consumers involved in consuming halal food products which has not yet been investigated, which is the category of non-South African consumers whether Muslims or non-Muslims. This category constitutes about 72,184 of the population group of Cape Town city with the percentage of $1.93 \%$ (Census, 2011). Since there are no reliable statistics with relation to these consumers intention towards buying halal food products, we decided to focus on this category in our research.

\section{Review of literature and hypotheses Halal food products in South Africa}

South Africa is one of the five largestmanufacturers of halal products worldwide and broadly regarded as a gateway to the continent's halal food and beverage market. South Africa's halal industry has changed it into a Sub-Saharan Africa's halal powerhouse, with its halal business valued at $\$ 3.22$ billion (SalaamGateway.com, 2017). Although the population of Muslims in South Africa is only around $2.5 \%$ of the country's total population, there is an increased focus in meeting the needs of these Muslim consumers. Furthermore, South Africa contributes $25 \%$ of the African continents' total gross domestic product (GDP). Despite its small percentage of Muslims, which is 1.2 million, South Africa has emerged as a leader in halal food industry because of the presence of highly advanced halal certification programmes. Although South Africa before 1994 was governed under the Apartheid Regime, the respect of religious practice was not restricted. The demand for halal products and services is increased amongst the Muslim population, mainly Muslims of Indian decent and Muslims known as Cape Malays, who consist of the decedents of Indonesian slaves brought to the Cape during colonial times is in this country. There is a growing population of Muslims converts, as well as Muslims from other countries such as Somalia and Bangladesh.

Concerning the non-Muslim community, there is awareness in halal products. Primarily, it is believed to be the same as Kosher, and many of the non- Muslim South Africans are not sufficiently enlightened about the halal requirements. In addition, consumers particularly Muslims are very cautious in purchasing halal products particularly in relation to the food consumption, personal care products, hotels, and restaurants because of religion obligation. Although the value system of Muslim consumers differ from other non-Muslim consumers in relation to consume food products (Varinli, Erdem, \& Avcılar, 2016). Muslim consumers are also similar to other consumers, demanding

healthy and quality products, which necessarily comply with Shariah requirements (AlHarran \& Low, 2008). Moreover,Muslim consumers are more aware of the importance of consuming halal foods, which indirectly leads to the extension of global halal food industry (Man \& Sazili, 2010). 


\section{Theory of planned behaviour (TPB)}

TPB is a theory suggested by Icek Ajzen that shows a relationship between beliefs and behaviour (Ajzen, 1991). TPB has been demonstrated to be the best way in predicting individual on consumption intention (Ajzen, 1991; Taylor \& Todd, 1997), and has been applied to study the relations among attitudes, subjective norms, and perceived behaviour control to determine the intentions and behaviours of individuals (Ajzen, 2005). In addition, TPB provides a social-psychological framework to understand and predict the determinants of human behaviour and integrates some of the fundamental concepts in the social and behaviour sciences (Armitage \& Conner, 2000).

TPB was applied to examine how attitude, subjective norms, and perceived behaviour control can influence the intention. Subsequently, it influences the behaviour of non-South African consumers to buy halal food products. In addition to the TPB factors, the awareness of nonSouth African halal consumers, which represents another factor may affect the intention and afterwards the behaviour of non-South African consumers will be examined. TPB is considered as relevant in studying consumer preferences in buying food products as many researchers in previous studies (Abdul Latiff \& Ayob, 2014; Rezai, Puah, Mohamed, \& Shamsudin, 2012; Shah Alam \& Mohamed Sayuti, 2011) had successfully applied it. It is a convenient model, which is useful in predicting the consumer purchasing behaviour. Many authors have recommended the efficiency of this model to measure halal purchase intention (Afendi, Azizan, \& Darami, 2014; Khalek \& Ismail, 2015; Zulariff \& Mohamad, 2014).

According to TPB, attitude towards the behaviour, subjective norms, and perceived behavioural control typically predict behavioural intentions. However, the research model proposed in this study shown in Figure 1 is based on TPB. The intention of halal food purchasing preceded the process before actual purchase or buying behaviour, as the intention reflects future behaviour. Accordingfy, awareness has a relationship with buying intention and buying behaviour. Attitude, subjective norms, and perceived behavioural control all have direct relationships with buying intention. Finally, buying intention has a relationship with consumers' buying behaviour. Based on the proposed research model, there are five hypotheses to be tested. Figure 1 shows the research model and hypotheses tested in this study. 


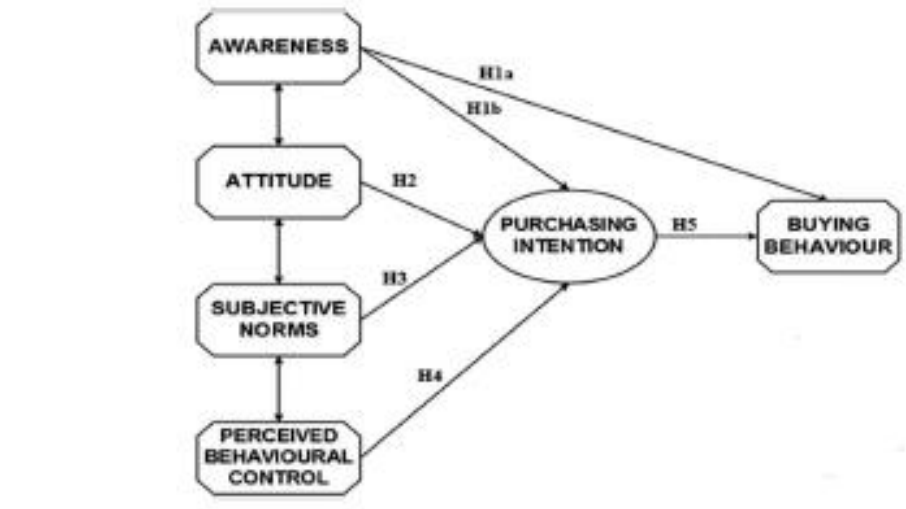

Figure 1. Purchasing-intention-decision model.

\section{Awareness of halal}

Awareness of halal literallymeans having a particular interest in or experience of halal, besides being knowledgeable of halal foods, drinks, and products (Ambali \& Bakar, 2014). Awareness refers to the understanding and information about specific things (Aziz \& Chok, 2013). Additionally, it is a relative concept where a person possibly will be, to some extent, subconsciously or very aware of the issues relating to halat aspect of what is allowable by Allah (God). Kertajaya and Ridwansyah (2014) state that without prior knowledge of the product, there is relatively high probability that consumer will not intend to buy the product, whether these products are relevant to halal products or non-halal products.

Moreover, the consumer's awareness of halal affect their decisions towards buying halal food products (Zakaria, Abdul Majid, Ahmad, Jusoh, and Zakaria (2017). Aziz and Chok (2013) emphasised that halal awareness has an influence on clarifying the intention to purchase halal products. Furthermore, Hamdan, Issa, Abu, and Jusoff (2013) in their study reveal that most influential factor in Muslim consumers' choices to buy halal food is the level of knowledge about dealing with the product. Although many studies have been conducted on the halal food industry and on halal consumer in Muslim majority countries (e.g. Afendi et al., 2014; Shah Alam \& Mohamed Sayuti, 2011), only a few studies attempt to investigate the problems in measuring the factors that affect the intention of consumers in majority of nonMuslim countries. There has been no detailed published research studies on non-South African halal consumers' intention as far as we are aware. Accordingly, the important research question in the study was as follows: How do individual factors influence halal consumers' intention and behaviour towards purchasing halal food products? To support the above research question, the next research sub questions are posed:

Q1. Do awareness, attitude, subjective norms, and perceived behavioural control significantly affect the purchase intention of halal food products?

Q2. Does awareness directly or indirectly affect the buying behaviour of halal food products? 
Q3. Does purchasing intention affect the buying behaviour of halal food products significantly?

However, the objectives of this study are:

- To determine if awareness, attitude, subjective norm,s and perceived behavioural control significantly influence purchase intention towards halal products.

- To determine the direct and indirect effect of awareness on buying behaviour towards halal food products.

- To determine the significant effect of purchasing intention on buying behaviour of halal food products.

\section{Awareness}

Generally, awareness refers to the human perception and intellectual response to the condition of what they eat, drink, and use (Ambali\&Bakar, 2014).Awareness is the procedure that is being taken in order to buy a product or service. It usually reflects the first step of the purchasing process, in which consumers who initially are not well versed with the product or service become familiar with it. In other words, awareness means the knowledge or understanding of particular subject or situation (Randolph, 2003). Previous research (Abd Rahman, Asrarhaghighi, \& Abd Rahman, 2015; Aziz \& Chok, 2013; Hamdan et al., 2013) have asserted that awareness has a positive influence on consumer attitude towards buying the food products. In addition, it has a positive effect on consumer intention (Krishnan, Aderis, Azman, \& Kamaluddin, 2017; Zakaria et al., 2017). Accordingly, the study hypothesises that:

H1a: Awareness about halal products has a positive and significant impact on consumer buying behaviour towards buying halal food products.

H1b: There is a positive correlation between awareness and consumer purchase intention towards buying halal food products.

\section{Attitude}

Ajzen (1991) defines attitude towards a behaviour as "the degree to which a person has a favourable or an unfavourable evaluation of a behaviour in question", it shows the performance of individual's behavioural intentions are positively or negatively valued (Ajzen, 2005). Attitude was measured based on previous studies done by Aditami \& Soepatini (2016) and Taylor \& Todd (1995). According to previous studies, attitude has a significant and positive influence on purchasing intention, which is drawn from consumers' positive attitude towards halal food products (Abd Rahman et al., 2015; Mukhtar \& Butt, 2012; Shah Alam \& Mohamed Sayuti, 2011). Therefore, more intention has been paid to purchase halal food products. Accordingly, the study hypothesises that: 
H2: There is a positive correlation between attitude and consumer purchase intention towards buying halal food products.

\section{Subjective norm}

Subjective norm refers to the consumers' perception towards social normative impetus (Ajzen, 2005), which may include family, friends, colleagues, relatives, or other such significant groups (Ajzen, 1991, 2005). These samples may offer the pressures on individuals. Subjective norm is the social pressure that a person feels to indulge or not indulge in a particular behaviour (Ajzen, 2005). Subjective norm is measured based on previous studies (Aditami \& Soepatini, 2016; Armitage \& Conner, 1999; Dean, Raats, \& Shepherd, 2012). Prior research done by Bonne, Vermeir, Bergeaud-Blackler, \& Verbeke (2007), Sukato (2008), and Yoh, Damhorst, Sapp, \& Laczniak (2003) argued that consumers' decisionmaking on product choice is certainly influenced by friends and family members. Accordingly, the study hypothesises that:

H3: There is a positive correlation between subjective norm and consumer purchase intention towards buying halal food products.

\section{Perceived behavioural control (PBC)}

Perceived behavioural control $(\mathrm{PBC})$ refers to "people's perception of the ease or difficulty of performing the behaviour of interest" (Ajzen, 1991). It is an individual's ability to perform a given behaviour (Ajzen, 2005). At the same time, $\mathrm{PBC}$ influences the intention and behaviour both directly and indirectly through behavioural intention (Noar \& Zimmerman, 2005). PBC comprises of three variables namely: ability, controllability, and availability. PBC was measured based on the previous studies (Aditami \& Soepatini, 2016; Chen \& Peng, 2012; Dean et al., 2012; Sparks, Guthrie, \& Shepherd, 1997; Taylor \& Todd, 1995). In addition to that, Ajzen (2005) emphasised that consumers need to uphold a certain degree of actual control in order to give themselves self-confidence in carrying out the behavioural intentions. Due to the combination of intentions and perceived behavioural controls one can predict human behaviour (Ajzen, 1991). This leads to perceived behavioural control (Ajzen, 2002). Accordingly, the study hypothesises that:

H4: There is a positive correlation between perceived behavioural control and consumer purchase intention towards buying halal food products.

\section{Consumer's purchase intention and buying behaviour}

Purchase intention refers to individual's readiness and willingness to purchase a certain product or service (Ajzen, 1985), and it can influence the purchasing decision of consumers in the future (Omar, Mat, Imhemed, \& Ali, 2012). This can be considered as one of the mechanisms of consumer cognitive behaviour on how a consumer intends to purchase a certain product (Hosein, 2012). Additionally, purchase intention is the direct originator of behavior (Ajzen, 1991). According to Ajzen (1985), purchase intention is the state where an individual is willing to perform a behaviour. Accordingly, Ajzen and Fishbein (1980) defined actual purchase behaviour as the individual's willingness to purchase specific manufactured

\section{http://repository.uwc.ac.za}


goods or services. Purchase intention was measured based on the previous studies (Kumar \& Mokhtar, 2016; Taylor \& Todd, 1995). Several empirical studies also show that intention can be a reliable predictor of behaviour. Davies and Wright (1994) explain that buying behaviour comes from the adequate awareness towards product. Therefore, the study hypothesises that:

H5: There is a positive correlation between purchase intention and buying behaviour of non-South African towards buying halal food products.

\section{Methodology}

Data collection and sample A random sampling method was used. Randomised samples of 300 respondents were targeted, which represent different people and different geographical areas in Cape Town city. This sample size was suitable as it is suggested and the recommended value set by (Comrey \& Lee, 1992; Hair, Black, Babin, Anderson, \& Tatham, 2010). The questionnaire for this study was established based on the document that was presented on Ajzen's website, which entitled "Constructing a TPB questionnaire" (Ajzen, 2002; Francis et al., 2004). This document helped in constructing the survey instrument relevant to this study. According to that, a self-administrated questionnaire was utilised to collect information regarding non-South African halal consumers' purchasing intention and awareness towards buying halal food products. The questionnaires were distributed in different areas and places in Cape Town eity, ineluding restaurants, shops, Mosques, and public places such as gardens, libraries, and train station. The purpose of study and questions were explained to the respondents. Therefore, they could just fill the questionnaire. In addition, before handing in the questionnaires, the respondents were asked if they consume halal food products.

After collecting the 230 questionnaires, these questionnaires were implicit and entered into Excel sheet for further analysis. A sêt of items tô create questionnaires were administrated based on previous literature. The questionnaire was initially written in English and then translated into Arabic. Totally, 280 responses were received, out of which only 230 were found usable and comprehensive. Therefore, the response rate was $77 \%$, and it shows appropriate statistical reliability and generalisability (Stevens, 2012). However, some 22 questionnaires were rejected because it had more than $10 \%$ missing values in dependent variables, which were not acceptable according to the statistics guidance (Hair, 2010), In addition, there were 28 discarded questionnaires which were filled by South African halal consumers while those were not targeted in this study. Whereas the rest of 20 questionnaires did not return. For data analysis, reliability, descriptive, structural equation modelling (SEM) analysis have been used.

\section{Analysis method}

SPSS software version 24 was utilised in this study to analyse all the data. Reliability and descriptive analysis both were used to analyse the consistency and demographic information respectively. In addition, the hypotheses are tested by applying SEM, which is a relatively robust method of analysis. SEM represents a philosophy that differs significantly from that typically followed in marketing modelling (Steenkamp \& Baumgartner, 2000). However, the

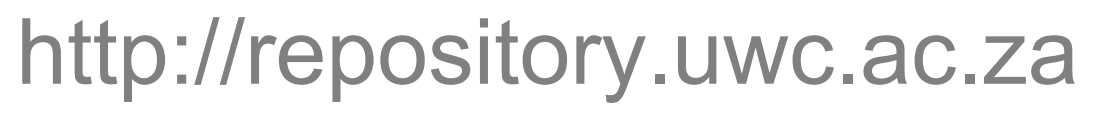


questionnaire was divided into three sections. The first section comprised of the respondents' socio-demographic characteristics, which includes age, gender, marital status, religion, nationality, education level, and occupation. The second section consisted of statements concerning non-South African halal consumers' awareness. The third section was comprised of halal consumers' attitude, subjective norms, and perceived behavioural control towards buying halal food products.

Five Likert-type items which measured the response of the questionnaire was used which are Strongly Disagree (1), Disagree (2), Neutral (3), Agree (4), and Strongly Agree (5) (Vagias, 2006). Likert scale is a measurement scale used to measure attitudes, opinions, and one's perception of social phenomena. According to Gwinner (2006), collective agreement from the forum stated that five (5) point scale is the most appropriate when conducting a survey.

\section{Research instrument}

The instrument of this study was developed based on the TPB framework, which consists of three constructs namely attitude, subjective norms, and perceived behavioural control in addition to awareness. The items were developed using the guidelines of constructing questionnaire proposed by its originator Izek Ajzen. All items went through the process of modification and rephrasing in order to fit the context of non-South Africans' halal consumption intention and behaviour. To ensure the content and construct validity of the research, two scholars seek agreement between a theoretical concept and a particular measuring procedure validated the questionnaire. In addition, the questionnaire was pretested by 20 respondents. In a quantitative research, validity refers to the degree to which a study precisely reflects or measures the specific concept that researcher is trying to measure. Therefore, to increase the validity and reliability of the results of this study, all the items have been adapted from previously validated studies (Straub, 1989) and any changes required to fit the instruments to the current sample context were appropriately performed. Based on rigorous instrument search, the reflective type measurement items for the study's variables were adopted.

\section{Findings}

\section{Reliability analysis}

Cronbach's alpha reliability coefficient was used to measure the internal reliability of the questionnaire, and the values obtained for each variable are illustrated in Table 1, which shows that all variables had reliability values of more than 0.8 (ranging from 0.873 to 0.945 ), thereby suggesting that the questionnaire items are reliable on their ability to measure the respective constructs consistently. Cronbach's alpha according to Nunnally (1978) has indicated 0.70 to be an acceptable reliability coefficient. 


\begin{tabular}{|c|c|c|c|c|}
\hline \multicolumn{5}{|c|}{ Reliability Analysis of Constructs } \\
\hline & Variable & & No. of Items & Cronbach's Alfa \\
\hline 1 & Attitude & ATT & 5 & 0.932 \\
\hline 2 & Subjective norm & $S N$ & 4 & 0.904 \\
\hline 3 & Percelved behavioural control & $\mathrm{PBC}$ & 4 & 0.945 \\
\hline 4 & Awareness & AW & 3 & 0.874 \\
\hline 5 & Purchase intention & PI & 3 & 0.873 \\
\hline 6 & Buying behaviour & $B B$ & 3 & 0.877 \\
\hline
\end{tabular}

\section{Descriptive analysis}

Socio-demographic information In this study, descriptive analysis was used to describe the socio-demographic profile of the respondents. The study focused on Cape Town city in the province of Western Cape in South Africa, where 230 non-South African halal consumers that consists of $(78.3 \%)$ males and (21.7\%) females were involved. Among the respondents $56.5 \%$ of them are married and $43.5 \%$ are single. They are also grouped into six age group categories, which are below 21 years, $(21-30)$ years, $(31-40)$ years, $(41-50)$ years, $(51-60)$ years, and 60 years and above. By looking at Table 2, most of the respondents were at the age below 21 years old (35.2\%). Although they are all non-South African consumers, but they have different beliefs as they have a different religion. Islam remains as the highest group amongst other religions (75.2\%). This is because most of the participants in this study were Muslims. However, the second largest religious group is Christian (17\%). All the respondents also came from various educational backgrounds. Out of 230 respondents, 77 (33\%) were postgraduate students, followed by secondary students (27\%). The lowest education level was primary students (11.3\%). Regarding occupation, most of the respondents are students (37.8\%), followed by self-employed (27.8\%). Finally, the nationality of the respondents, most of the respondents are Libyans (18.7\%), followed by Egyptians (15.7\%).

\section{Hypotheses results}

After the study is translated into the hypotheses model as shown in Figure 1, observed variables are drawn with the error terms for each latent variable. For the exogenous variables, attitude (ATT) contains five observed variables, while subjective norm (SN) and perceived behavioural control (PBC) each one contains four observed variables.

\section{Structural equation modelling (SEM)}

The method of analysis employed in this study is the SEM, which was done via Amos and SPSS version 24. The SEM is used to test the effects in the relationships stated in research assumptions/questions (Cheung \& Rensvold, 2002). Obtaining a fitted SEM is pertinent to achieving the objectives of this study. According to Hooper, Coughlan, and Mullen (2008) the following indices are important in realising a fitted structural model. Relative Chi-Square should be less than 3.00 (if sample size is less than 200); incremental fit index (IFI) should be less than 0.90; comparative fit index (CFI) should be less than 0.90; root mean square error of approximation (RMSEA) should be less than 0.08 and a PCLOSE greater than 0.05. Hooper et al. (2008) noted that chi square index is sensitive to sample size, small or large. They therefore advised that caution should be exercised in the interpretation of the index. However, it is common practice to report the chi square index, but just ignore it for more reliable indices, when it comes to reporting on the goodness of fit for SEM.

\section{http://repository.uwc.ac.za}




\begin{tabular}{|c|c|c|c|}
\hline Demographic Variables & Item & Frequency & Percent (\%) \\
\hline \multirow[t]{2}{*}{ Gender } & Male & 180 & 78.3 \\
\hline & Female & 50 & 21.7 \\
\hline \multirow{6}{*}{ Age } & Below 21yrs & 81 & 35.2 \\
\hline & $21-30 y r s$ & 71 & 30.9 \\
\hline & $31-40 y r s$ & 45 & 19.6 \\
\hline & $41-50 y r s$ & 22 & 9.6 \\
\hline & $51-60 y r s$ & 11 & 4.8 \\
\hline & $61 y r s$ and above & 0 & 0 \\
\hline \multirow{3}{*}{ Marital status } & Single & 100 & 43.5 \\
\hline & Married & 130 & 56.5 \\
\hline & Other & 0 & 0 \\
\hline \multirow[t]{6}{*}{ Religion } & Muslim & 173 & 75.2 \\
\hline & Christian & 39 & 17 \\
\hline & Buddhist & 1 & 4 \\
\hline & Jewish & 11 & 48 \\
\hline & Hindu & 5 & 22 \\
\hline & Other & 0 & 0 \\
\hline \multirow{5}{*}{ Occupation } & Student & 87 & 37.8 \\
\hline & Employee & 33 & 14.3 \\
\hline & Unemployed & 45 & 19.6 \\
\hline & Self-Employed & 64 & 27.8 \\
\hline & Other & 1 & 0.4 \\
\hline \multirow[t]{5}{*}{ Education Level } & Primary & 26 & 11.3 \\
\hline & Secondary & 62 & 27 \\
\hline & Undergraduate & 58 & 25.2 \\
\hline & Post graduate & 77 & 33.5 \\
\hline & Other & 0 & 0 \\
\hline \multirow{23}{*}{ Nationality } & Somali & 19 & 8.3 \\
\hline & Libyan & 43 & 18.7 \\
\hline & Sudanese & 17 & 7.4 \\
\hline & Egyptian & 36 & 15.7 \\
\hline & Moroccan & 15 & 6.5 \\
\hline & $\begin{array}{l}\text { Palestine } \\
\text { Indian }\end{array}$ & 24 & $\begin{array}{r}10.4 \\
-\quad 3.9 \\
\end{array}$ \\
\hline & Bangladesh 11 & 31 & 171.3 \\
\hline & Saudi Arabian & 5 & 2.2 \\
\hline & European countri & 17 & 7.4 \\
\hline & Angolan & 8 & 3.5 \\
\hline & Brazllian & 5 & 2.2 \\
\hline & Yamani & 1 & 0.4 \\
\hline & Nigerian & 3 & 1.3 \\
\hline & Congo & s] & 2.2 \\
\hline & Namibian $\mathrm{I}^{\mathrm{f}}$ & 2 & 089 \\
\hline & Eritrean & 2 & 0.9 \\
\hline & Turkey & 2 & 0.9 \\
\hline & Tanzanian 1 & 3 & $t / 13^{\prime}$ \\
\hline & Zimbabwean & $\begin{array}{l}3 \\
3\end{array}$ & 1.3 \\
\hline & $\begin{array}{l}\text { Burundiae } \\
\text { Gamblan W I }\end{array}$ & $\mathrm{R}_{1}^{3} \mathrm{~V}$ & $\mathrm{P}_{0.4}^{1.3}$ \\
\hline & Malaysian & 1 & 0.4 \\
\hline & Malawi & 1 & 0.4 \\
\hline & Rwandan & 1 & 0.4 \\
\hline
\end{tabular}

\section{The structural model}

Depicts the structural equation model for the conceptual model. From this model, there are six (6) variables involved in the study. Some factors as stated in Table 1 measure each of the variables. The boxes labelled as aw1, aw2, aw3, etc. represent the factors used to measure each construct (i.e. AW, ATT, SN, PBC, PI \& BB); while the circles labelled as e1-e30 are the error terms associated with the factors. The single-headed arrows measure the regression weights while the double-headed arrows measure correlation/covariances. 


\section{Model fitness and fitted model}

Through a process of model fitness, some factors and variables were eliminated in order to realise a model that fits the dataset. The results which are presented in Table 3 show that the model has a good fit with the dataset and thus, its results are reliable.

\section{Fitted model results}

Based on the fit indices discussed above, a fitted structural model was derived and the results of standardised regression weights and correlation estimates are presented in Table 4 and Table 5. From Table 4, we examined the statistical significance of each factors used to estimate the study variables such as awareness (AW), attitude (ATT), subjective norm (SN), perceived behavioural control (PBC), purchase intention (PI), and buying behaviour (BB). The results show that all the factors in the fitted model whose regression weights range between 0.797 and 0.936 are all statistically significant at $p$ value less than 0.001 . The regression weights also show high loading of factors on their respective variables. The critical ratios (CR) for all the factors are above the critical value of 1.96, implying that the factors are all significant in the measurement of the study variables.

Table 3. Model Fit Results

\begin{tabular}{|c|c|c|}
\hline Index & Obtained Value $\quad$ Gritical Value & Model Fit \\
\hline $\begin{array}{l}\text { Chi-Square ( } P \text { value) } \\
\text { Relative Chi-Square }\end{array}$ & $\begin{array}{l}0.000 \\
2283\end{array}=0.05$ & $\begin{array}{l}\text { Algnore } \\
\text { Good }\end{array}$ \\
\hline Comparative Fit Index (CFI) & $0953+11 \square 110.9010$ & cood \\
\hline Incremental Fit Index (FI) & $6954=$ & Good \\
\hline $\begin{array}{l}\text { Rock Mean Square Error of Approximation (RMSEA) } \\
\text { PCLOSE }\end{array}$ & 0975 & cood \\
\hline
\end{tabular}

"Chi-square fit index is usually only reported, but ignogred when determining the fitness of a structural model because it is reactive to sample size.

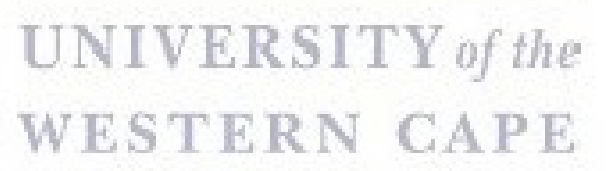




\begin{tabular}{|c|c|c|c|c|c|c|}
\hline & & & Standardised Estimate & S.E. & C.R. & $p$ \\
\hline PI & $<-$ & ATT & 0.5 & 0.117 & 4.623 & $m$ \\
\hline PI & $<-$ & SN & 0.243 & 0.126 & 1.947 & 0.052 \\
\hline PI & $<-$ & PBC & 0.082 & 0.074 & 1.093 & 0.275 \\
\hline PI & $<-$ & AW & 0.147 & 0.102 & 1.644 & 0.1 \\
\hline$B B$ & $<-$ & PI & 0.5 & 0.113 & 4.766 & $\cdots$ \\
\hline$B B$ & $<-$ & AW & 0.4 & 0.127 & 3.837 & $\cdots$ \\
\hline a1 & $<-$ & ATT & 0.797 & & & \\
\hline a2 & $<-$ & ATT & 0.867 & 0.058 & 18.662 & $\cdots$ \\
\hline a3 & $<-$ & ATT & 0.893 & 0.069 & 15.942 & $\cdots$ \\
\hline 24 & $<-$ & ATT & 0.877 & 0.071 & 15.528 & $\cdots$ \\
\hline as & $<-$ & ATT & 0.861 & 0.071 & 15.078 & $\cdots$ \\
\hline$s 1$ & $<-$ & $S N$ & 0.844 & & & \\
\hline 53 & $<-$ & $S N$ & 0.773 & 0.064 & 13.745 & $\cdots$ \\
\hline 54 & $<-$ & $S N$ & 0.854 & 0.062 & 16.096 & $\cdots$ \\
\hline$\$ 2$ & $<-$ & $S N$ & 0.794 & 0.06 & 14.323 & $\cdots$ \\
\hline p1 & $<-$ & PBC & 0.873 & & & \\
\hline p3 & $<-$ & PBC & 0.918 & 0.053 & 19.686 & $\cdots$ \\
\hline p4 & $<-$ & PBC & 0.936 & 0.059 & 17.758 & $\cdots$ \\
\hline$p 2$ & $<-$ & PBC & 0.865 & 0.038 & 25.005 & $\cdots$ \\
\hline aw1 & $<-$ & AW & 0.801 & & & \\
\hline aw3 & $<-$ & AW & 0.856 & 0.081 & 14.517 & $m$ \\
\hline$a w 2$ & $<-$ & AW & 0.859 & 0.079 & 14.582 & $\cdots$ \\
\hline i1 & $<-$ & PI & 0.793 & & & \\
\hline 13 & $<-$ & PI & 0.87 & 0.068 & 14874 & $\cdots$ \\
\hline 12 & $<-$ & PI & 0.838 & 0.073 & 14.163 & $\cdots$ \\
\hline b3 & $<-$ & $B B$ & 0.797 & 0.067 & 13.325 & $\cdots$ \\
\hline b1 & $<-$ & $B B$ & 0.872 & & 4.623 & \\
\hline
\end{tabular}

Table 5. Correlation Estimates of Variables in the Fitted Structural Model.

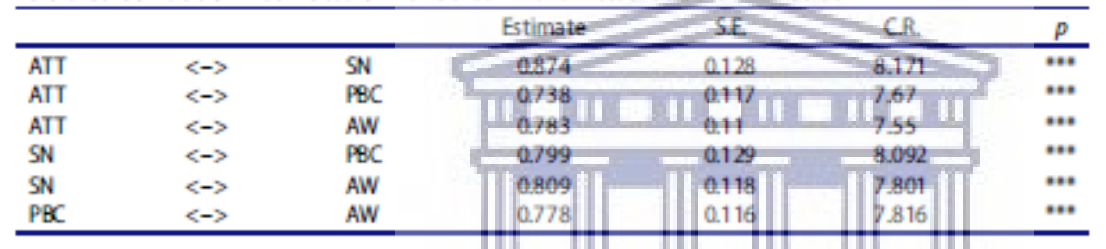

By the above results, we went further to examine the impact of the awareness, attitude, perceived behavioural control, and subjective norm on purchasing intention towards halal food products. The standardised regression weights were estimated to measure the impact. The results show that attitude (ATT) significantly affects purchasing intention (PI); while purchasing intention (PI) and awareness (AW) both affect significantly on buying behaviour (BB) towards halal food products. However, subjective norm (SN) and perceived behavioural control (PBC) do not significantly affect purchasing intention.

To examine the direct and indirect effects of awareness (AW) about halal products on the buying behaviour (BB) towards halal products, we estimated the standardised directs at 0.4 and the standardised indirect effects at 0.075 (i.e. 0.15 , which is the direct effect of AW on PI multiplied by 0.50 , which is the direct effect of PI on BB). The standardised direct effect of 0.4 implies that awareness, without the mediation of any other factor, accounts for $40 \%$ variation in buying behaviour towards halal food products. This is a critical input for marketing strategy for halal food manufacturers. However, the standardised indirect effect through the mediation of purchasing intention accounts for less than 9 percent variation in buying intention. Besides, the fact that 9 percent is low, it can also be questioned based on the prior result of the insignificant relationship that exists between awareness (AW) and 
purchase intention (PI). Thus, the direct effect of awareness (AW) on buying behaviour (BB) is more statistically useful for decision-making than its indirect effect.

\section{Correlation estimates}

The study variables were correlated and the correlation estimates shown in Table 5 range from 0.738 and 0.874 . These estimates indicate that the variables are strongly correlated. The critical ratios, which are all greater than the critical value of 1.96 , as well as the p-value, which are all less than 0.05 , show that the correlation estimates are statistically significant.

\section{Discussion}

The aim of this study was to investigate the factors that influence non-South African consumers towards buying halal food products in Cape Town. The TPB was employed to provide a theoretical basis for the conceptualised framework. Five hypotheses were suggested and in order to test these hypothesised relationships, primary data were collected from non-South African consumers who are living in different geographical locations in Cape Town. The empirical findings do not provide support to all the proposed hypotheses, with two out of five hypotheses being supported in a significant way.

In agreement with H1a, the findings showed that respondents held a positive awareness (AW) which leads directly to affect their buying behaviour (BB) toward buying halal food products. This is shown in Figure 2. The positive and significant (at $\mathrm{p}<0.01$ ) correlation between awareness (AW) and buying behaviour (BB) towards halal food was confirmed by previous studies (e.g., Aziz \& Chok, 2013; Hamdan et al., 2013), which suggested that halal awareness has an effect on clarifying the intention to purchase halal products. This is because the consumers who have a high awareness about halal seemed to have greater intention towards purchasing halal food products.

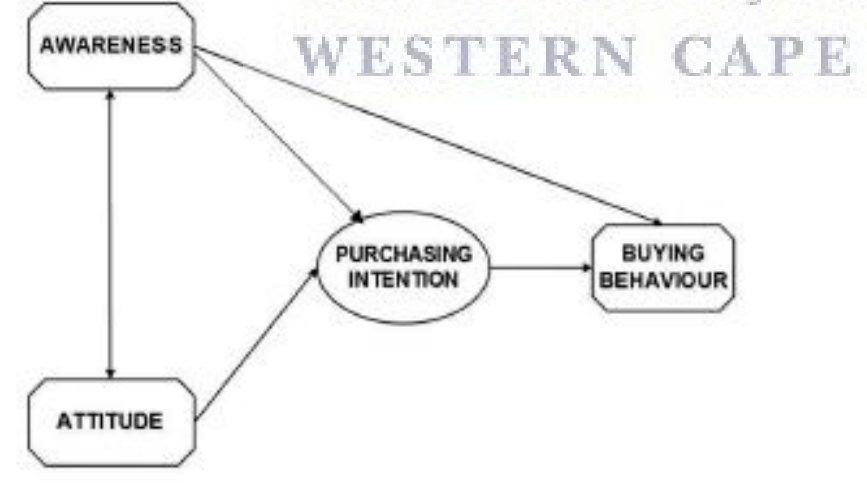

Figure 2. Depicts the conceptual model.

In agreement with $\mathrm{H} 1 \mathrm{~b}$, the findings showed that there was a positive correlation between awareness (AW) and consumer purchase intention (PI) as shown in Figure 2. Findings of the study were supported by previous studies agreed with the results (Aziz \& Chok, 2013; Hamdan et al., 2013; Yunus et al., 2014). This is because awareness has been hypothesised as an important factor in determining the intention to choose halal food, particularly amongst 
Muslims consumers (Yunus et al., 2014). In addition, Muslim consumers are now more aware of their food consumption (Abdul-Talib \& Abd-Razak, 2013). This is also supported by Abdul Manaf Bohari (2013) who stated that because of the increasing awareness among Muslims population, there is a need for them to consume halal products that according to Islamic requirements, and consequently it will increase the demand on halal products among Muslim population all over the world.

Likewise, in support of $\mathrm{H} 2$, the study findings revealed that there was a positive correlation between attitude (ATT) and purchase intention (PI) as shown in Figure 2. This effect was found to be significant and was in agreement with the findings from studies done by Abd Rahman et al. (2015), Haro (2016), Lada, Tanakinjal, \& Amin (2009), Mukhtar \& Butt (2012), and Shah Alam \& Mohamed Sayuti (2011). This is because the consumer with high positive attitude seemed to have higher intention to purchase halal food products. Another reason is that the TPB hypothesised that a stronger attitude to a certain behaviour leads to a greater intention to perform that behaviour (Ajzen, 1991, 2005). This suggestion is in agreement with the conclusions made by (Afendi et al., 2014; Baker, Al-Gahtani, \& Hubona, 2007; Yoo \& Norton, 2007) who found the similar results. The finding of the study suggests that when attitude of consumers positively increase, therefore, their possibility to buy halal food products will also increase. As a positive attitude has a positive direct effect on intention (Ajzen, 1991).

However, in disagreement with $\mathrm{H}_{3}$, the results confirmed that an inverse relationship exists between subjective norm (SN) and purchase intention (PI). Although the social pressures (families, friends and others) affect the intention of conducting a certain behaviour (Nastasha, 2015). Social pressures also have high influence on intention towards halal food (Puschel, Mazzon, \& Hernandez, 2010). These findings are not in line with the results obtained by Afendi et al. (2014) annd Karijin, Iris, Florence, \& Wim (2007). Similarly, these findings diverged from research studies where subjective norm is a significant factor for halal food consumption (Bonne et al., 2007; Golnaz, Zainulabidin, Mad Nasir, \& Eddie Chiew, 2010). Additionally, these findings were not consistent with the theory of planned behaviour (Ajzen, 1991, 2005). For the findings of the study, social pressure was not able to provide any positive concerning a reason for buying halal food products to consumers. In spite of the prior studies found that subjective norm is one of the most commonly stated drives for buying halal food products (e.g. Sukato, 2008; Yoh et al., 2003), the findings of this study were not in an agreement with what concluded in these studies. This might be because the respondents reside out of their countries, and they were not surrounded with their social environment.

In divergence with $\mathrm{H}_{4}$, the results confirmed that an opposite relationship occurs between perceived behavioural control (PBC) and purchase intention (PI) towards buying halal food products. The effect was not found to be significant, and this finding contradicted with the results carried by several previous researchers (e.g. Afendi et al., 2014; Karijin et al., 2007). The findings of the study, therefore, were contrary to the findings in Noar and Zimmerman (2005). This means that PBC of halal food does not have positive relationship with purchase

\section{http://repository.uwc.ac.za}


intention of buying halal food products. This is because consumers tend to perceive themselves as interdependent with their group and tend to strive for in-group rather than individual goals (Karijin et al., 2007) or may be the consumers do not feel that they have more control in taking the decisions to buy halal food products. Based on the TPB variables, only attitude has a positive and significant correlation with consumers' intention, while subjective norms and perceived behavioural control have not. Consequently, the current study does not provide a support for all the dimensions of the TPB (Ajzen, 1991, 2005).

In disagreement with $\mathrm{H}_{5}$, the relationship between purchase intention (PI) and buying behaviour (BB) towards purchasing halal food products was not found to be significant. This finding in disagreement with the findings carried by previous researchers such as (Ajzen, 1991; Omar et al., 2012), which suggested that if the consumer does not have a high intention, this would not lead to buying halal food products. In addition, there is not a perfect relationship between purchase intention and buying behaviour. As consumers' intention may not be an accurate representation of consumers' buying behaviour. Thus, consumers who has no intention towards halal food products are not ready to buy them.

\section{Contribution and originality of the study}

This study has several significant contributions. Academically, this research is one of the first attempt to test a conceptual model on halal consumers' purchase intention by integrating halal studies with marketing-related studies in South Africa. Regarding the theoretical contribution, this study is important because of its contribution towards an insight on how consumers are becoming more aware about halal food products. It can be used to develop halal products to attract both Muslim and non-Muslim consumers who are foreign to a particular country. Moreover, to increase the confidence amongst not only Muslim consumers, but also non-Muslim consumers to support their products. Empirically, this study provides an evidence of the significant relationships between halal awareness and buying behaviour. Besides, the significant relationship between consumers' attitude and purchase intention. Another contribution was that, this study is the first study provides statistic information about halal consumers' intention and behaviour in South Africa in general and Cape Town city in particular. The contribution is particularly valuable for not only local marketing, but also for global marketing researchers and traders, as it presents recommendations and suggestions regarding empirical applications and paves the way for forthcoming research studies.

\section{Conclusion}

The findings of this study indicate that there is a significant relationship between awareness and buying behaviour. Importantly, this study concluded that most non-South African consumers are aware of the importance of halal food products. This might be due to the adequate knowledge and familiarity on halal and the benefits of consuming halal food products. The results also show that non-South African consumers' attitude has a significant positive relationship with intention towards purchasing halal food products. While, the subjective norms and perceived behavioural control did not have significant on consumers' intention towards halal food products. One of the most important conclusions that may be

\section{http://repository.uwc.ac.za}


drawn from this study lies in the fact that halal awareness and consumers' attitude are significant factors in explaining the intention to purchase halal product among non-South African consumers. Therefore, understanding consumers' attitude and awareness would be a benefit in order to produce and offer halal products in South African markets.

As a conclusion, awareness and attitude were found to be the most significant factor in predicting the purchase intention of halal classified products. This is because of the different nature of halal food products consumption for Muslims than the consumption of other food products for non-Muslims. However, the findings of this study will be useful for the South African manufacturers and marketing managers of halal trade, as well as it will have a potential to be the basis of further explorations of halal food consumption for other South African scholars. For future research, additional studies on South African consumers to investigate the differences between local Muslims and foreigners insights regarding consumer intention is required. Similar to other empirical studies, this study is not without its limitations. Due to the time and situational constraints, the respondents were only limited to the Cape Town city in South Africa. A broader geographical area would have been better for generalising the findings to the general population.

\section{Funding}

This work was supported by the University of Western Cape;

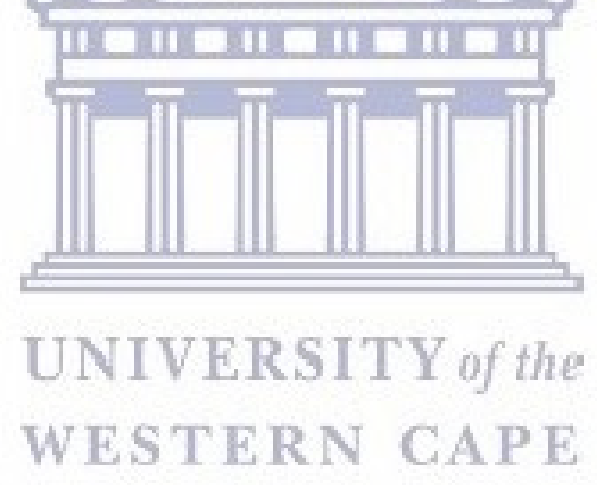




\section{References}

Abd Rahman, A., Asrarhaghighi, E., \& Abd Rahman, S. (2015). Consumers and halal cosmetic products: Knowledge, religiosity, attitude and intention. Journal of Islamic Marketing, 6(1), 148-163.

Abdul-Talib, A. N., \& Abd-Razak, I. S. (2013). Cultivating export market oriented behaviour in halal marketing: Addressing the issues and challenges in going global. Journal of Islamic Marketing, 4(2), 187-197.

Aditami, S. (2016). The Analysis of Halal Product Purchase Intention Using Theory Of Planned Behavior (TPB): An Application on Bakery Product Consumption (Doctoral dissertation, Universitas Muhammadiyah Surakarta) in Solo and Sukoharjo, Indonesia.

Afendi, N. A., Azizan, F. L., \& Darami, A. I. (2014). Determinants of halal purchase intention: Case in perlis. International Journal of Business and Social Research, 4(5), 118-123.

Ajzen, I. (1985). From intentions to actions: A theory of planned behavior. In J. Kuhl \& J. Beckman (Eds.), Action-control: From cognition to behavior (11-39). Germany, Springer Berlin Heidelberg.

Ajzen, I. (1991). Theory of planned behavior. Organizational behavior and human decision processes. 50(2), 179-211.

Ajzen, I. (2002). Perceived behavioural control, self-efficacy, locus of control, and the theory of planned behavior1. Journal of Applied Social Psychology, 32(4), 665-683. Ajzen, I. (2005). Attitudes, personality and behaviour (2nd ed.). Berkshire, England: Open University Press. McGraw-Hill Education (UK).

Ajzen, I., \& Fishbein, M. (1980). Understanding attitudes and predicting social behavior. Englewood Cliffs, NJ: Prentice-Hall.

Al-Harran, S., \& Low, P. (2008). Marketing of halal products: The way forward. The Halal Journal, 42-46. Kualal Lumpur; IKasehdia Sdn. Bhd. Al-Qur'anul Karim. Retrieved from http://www.halaljournal.com. Available at SSRN: https://ssrn.com/abstract $=1577795$.

Ambali, A. R., \& Bakar, A. N. (2014). People's awareness on halal foods and products: Potential issues for policy-makers. Procedia-Social and Behavioural Sciences, 121(2014), 3-25.

Armitage, C. J., \& Conner, M. (1999). Predictive validity of the theory of planned behaviour: The role of questionnaire format and social desirability. Journal of Community \& Applied Social Psychology, 9(4), 261-272.

Armitage, C. J., \& Conner, M. (2000). Social cognition models and health behaviour: A structured review. Psychology and Health, 15(2), 173-189.

Aziz, Y. A., \& Chok, N. V. (2013). The role of halal awareness, halal certification, and marketing components in determining halal purchase intention among non-muslims in Malaysia: A structural equation modelling approach. Journal of International Food \& Agribusiness Marketing, 25(1), 1-23.

Baker, E. W., Al-Gahtani, S. S., \& Hubona, G. S. (2007). The effects of gender and age on new technology implementation in a developing country: Testing the theory of planned behaviour (TPB). Information Technology \& People, 20(4), 352-375. 
Bamba, A., Talek, Y., \& Kaba, A. M. (2017). Halal food in multi African society and Muslim christian relations formation: A strategic vision in political and economic dimension. Humanities and Social Sciences Review, 07(01), 81-94.

Bernama. (2009). World halal food industry estimated to rise to Us $\$ 655$ billion. Retrieved November 6, 2016, from http://www.bernama.com/bernama/v5/newsbusiness.php?id=408763

Berry, B. (2008). Global halal food market brief, agriculture and agri-food Canada, Ottawa, Retrieved January 15, 2010, from http://ats.agr.gc.ca/afr/4491-eng.pdf

Bohari, A. M., Cheng, W. H., \& Fuad, N. (2013). An analysis on the competitiveness of halal food industry in Malaysia: an approach of SWOT and ICT strategy. Geografia: Malaysian Journal of Society and Space, 9(1), 1-11.

Bonne, K., Vermeir, I., Bergeaud-Blackler, F., \& Verbeke, W. (2007). Determinants of halal meat consumption in France. British Food Journal, 109(5), 367-386.

Census (2011) Census in brief/Statistics South Africa. Pretoria: Statistics South Africa, 2012. Retrieved September 27, 2016, from Census2011.adrianfrith.com

Chen, A., \& Peng, N. (2012). Green hotel knowledge and tourists' staying behaviour. Annals of Tourism Research, 39(4), 2211-2216.

Cheung, G. W., \& Rensvold, R. B. (2002). Evaluating goodness-of-fit indexes for testing measurement invariance. Structural Equation Modelling, 9(2), 233-255.

Comrey, A. L., \& Lee, H. B. (1992). A first course in factor analysis: Psychology press. Routledge ( $2^{\text {nd }}$ ed.). Hillsdale, NJ: Erlbaum.

Davies, M. A. P., \& Wright, I. T. (1994). The importance of labelling examined in food marketing. European Journal of Marketing, MCB University Press, 28(2), 57-67.

Dean, M., Raats, M. M., \& Shepherd, R. (2012). The role of self-identity, past behaviour, and their interaction in predicting intention to purchase fresh and processed organic food1. Journal of Applied Social Psychology, 42(3), 669-688.

Egan, M. (2002). Overview of halal from agri-canada perspective. Presented at the Fourth Intl Halal Food Conference; April 21- 23; Sheraton Gateway Hotel, Toronto, Canada.

Francis, J., Eccles, M. P., Johnston, M., Walker, A. E., Grimshaw, J. M., Foy, R., . . . Bonetti, D. (2004). Constructing questionnaires based on the theory of planned behaviour: A manual for health services researchers. Retrieved January 10, 2017, from Golnaz, R., Zainulabidin, M., Mad Nasir, S., \& Eddie Chiew, F. C. (2010). Non-muslim perception awareness of halal principle and related food products in Malaysia. International Food Research Journal, 17(3), 667-674.

Gwinner, C. (2006). 5-point vs. 6-point likert scales. Available at: www.infosurv com/wp-content/ uploads/2011/o1/Likert_Scale_Debate.pdf. InfosurvWhite Paper. Atlanta, state of Georgia, U.S. Hair, J. F. (2010). Multivariate data analysis. Pearson College Division. London, United Kingdom.

Hair, J. F., Black, B., Babin, B., Anderson, R. E., \& Tatham, R. L. (2010). Multivariate data analysis: A global perspective. New Jersey, USA: Pearson Education Inc.

Halal Industry Development Corporation. (2014). Opportunities in the halal economy. Malaysia. Retrieved July 01, 2017, from www.hdcglobal.com 
https://www.google.com.ly/search?safe=strict\&rlz/ $\quad$ https://issuu.com/the-halaljournal/docs/july aug2010

Halal Research Council. (2010). The global market potential of halal. international conference \& expo on halal industry Lahore, Pakistan. Retrieved July 5, 2017, from Repository. salaamgateway.com

Hamdan, H., Issa, Z. M., Abu, N., \& Jusoff, K. (2013). Purchasing decisions among Muslim consumers of processed halal food products. Journal of Food Products Marketing, 19(1), 54-61.

Hancock, T. (2015). R1bn halal food park a possibility for western cape in next two years. Retrieved June 28, 2017, from http://www.engineeringnews.co.za/article/r1bnhalal-foodpark-a-possibility-for-western-cape-in-next-two-years-2015-07-27

Haro, A. (2016). Understanding TPB model, availability, and information on consumer purchase intention for halal food. International Journal of Business and Commerce. 5(08), 47-56. Jakarta, Indonesia.

Hassan, F. H. (2013). Halal food marketing: Dare to win. Malaysia: UiTM Press. Shah Alam, Selangor Darul Ehsan, Malaysia.

Hooper, D., Coughlan, J., \& Mullen, M. R. (2008). Structural equation modelling: Guidelines for determining model fit. Electronic Journal of Business Research Methods, 6(1), 53-60.

Hosein, N. Z. (2012). Measuring the purchase intention of visitors to the auto show. Journal of Management and Marketing Researeh, 9(1) 1-17. Northwood - University, Midland, USA.

Karijin, B., Iris, V., Florence, B. B., \& Wim, V. (2007). Determinants of Halal Meat Consumption in France. British Food Journal, (109), 367-386.

Kertajaya, H., \& Ridwansyah, A. (2014). Wow Selling. Jakarta: PT. Gramedia Pustaka Utama. Jakarta, Indonesiâ.

Khalek, A. A., \& Ismail, S. H. S. (2015). Why are we eating halal-using the theory of planned behavior in predicting halal food consumption among generation $\mathrm{Y}$ in Malaysia. International Journal of Social Science and Humanity, 5(7), 608.

Krishnan, S., Aderis, M. H. H. M., Azman, M. N., \& Kamaluddin, M. N. A. (2017). Halal food: Study on non-muslim acceptance. American Journal of Economics, 7(1), 41-45.

Kumar, P., \& Mokhtar, S. S. M. (2016). Ethical marketing practices viewed through consumer spectacles. Market/Tržište, 28(1), 29-45.

Lada, S., Tanakinjal, H., \& Amin, H. (2009). Predicting intention to purchase halal products using theory of reasoned action. International Journal of Islamic and Middle Eastern Finance and Management, 2(1), 66-76.

Latiff, Z. A. A., \& Ayob, M. A. (2014). Food labels based on theory of planned behavior in klang valley. Infrastructure University Kuala Lumpur Research Journal, 2(1), 113118.

Majid, M. A. A., Abidin, I. H. Z., Majid, H. A. M. A., \& Chik, C. T. (2015). Issues of halal food implementation in Malaysia. Journal of Applied Environmental and Biological Sciences, 5(6S), 50-56. 
Man, Y. C., \& Sazili, A. Q. (2010). Food production from the halal perspective. In Handbook of Poultry Science and Technology: Primary Processing, (1), 183-215. John Wiley \& Sons, Inc. New Jersey, USA.

Marzuki, S. Z. S., Hall, C. M., \& Ballantine, P. W. (2012). Restaurant manager and halal certification in Malaysia. Journal of Foodservice Business Research, 15(2), 195214.

Mohamed, Z., Shamsudin, M. N., \& Rezai, G. (2013). The effect of possessing information about halal logo on consumer confidence in Malaysia. Journal of International Food \& Agribusiness Marketing, 25(sup1), 73-86.

Muhammad, N. M. N., Isa, F. M., \& Kifli, B. C. (2009). Positioning Malaysia as halalhub: Integration role of supply chain strategy and halal assurance system. Asian Social Science, 5 (7), 44-52.

Mukhtar, A., \& Butt, M. M. (2012). Intention to choose halal products: The role of religiosity. journal of Islamic Marketing, 3(2), 108-120.

Natasha, n. (2015). a study of the relationship between attitude, subjective norms, and perceived behavioural control of non-muslim consumers' towards intention to purchase halal food products in malaysia. Subjective Norms, and Perceived Behavioural Control of Non-Muslim Consumers' Towards Intention to Purchase Halal Food Products in Malaysia (December 1, 2015).

Noar, S. M., \& Zimmerman, R. S. (2005). health behavior theory and cumulative knowledge regarding health behaviours: Are we moving in the right direction? Health Education Research, 20(3), 275-290.

Nunnally, J. C. (1978). Psychometric Theory (2nd ed., pp. 245). New York, NY: McGraw-Hill.

Omar, K. M., Mat, N. K. N., Imhemed, G. A., \& Ali, F. M. A. (2012). The direct effects of halal product actual purchase antecedents among the international muslim consumers. American Journal of Economics, (2), 87t92.

Puschel, J., Mazzon, J., \& Hernandez, C. (2010). Mobile banking: Proposition of an integrated adoption intention framework. International Journal of Bank Marketing, 28(5), 389-409.

Randolph, G. (2003). Surgical anatomy of recurrent laryngeal nerve: In: Randolph GW, editor. Surgery of the thyroid and parathyroid glands. Saunders: Philadelphia, US, PA: 2003; 300-343. Elsevier.

Rezai, G., Puah, K. T., Mohamed, Z., \& Shamsudin, M. N. (2012). Consumers' awareness and consumption intention towards green foods. African Journal of Business Management, 6(12), 4496-4503.

Said, M., Hassan, F., Musa, R., \& Rahman, N. A. (2014). Assessing consumers' perception, knowledge and religiosity on Malaysia's halal food products. ProcediaSocial and Behavioural Sciences, 130, 120-128.

Salaam Gateway. Report: Free Zones Outlook. (2017). Shaping the growth of the Islamic economy. Featured report. Retrieved March 10, 2017, from http://www.salaamgateway.com 
Shah Alam, S., \& Mohamed Sayuti, N. (2011). Applying the theory of planned behaviour (TPB) in halal food purchasing. International Journal of Commerce and Management, 21(1), 8-20.

Sparks, P., Guthrie, C. A., \& Shepherd, R. (1997). The dimensional structure of the perceived behavioural control' construct. J. Appl. Psychol., 27, 418-438.

Steenkamp, J. B. E., \& Baumgartner, H. (2000). On the use of structural equation models for marketing modelling. International Journal of Research in Marketing, 17(2), 195-202.

Stevens, J. P. (2012). Applied multivariate statistics for the social sciences. London, UK: Routledge.

Straub, D. W. (1989). Validating instruments in MIS research. MIS Quarterly, 13(2), 147-169.

Sukato, N. (2008). Changes in male buying behaviour in Thailand - The case of "metrosexuals". The Management Case Study Journal, 8(2), 263-270.

Sungkar, I. R. F. A. N., Othman, P. A. Z. I. M., \& Hussin, W. W. (2008). Potentials of global halal food market: Implications for Vietnamese SMEs. The 33rd Annual Conference of the Federation of ASEAN'S Economic Associations - ASEAN's Cooperation and Agricultural and Rural Development in the Globalisation Era, Hanoi.

Taylor, S., \& Todd, P. (1995). Decomposition and crossover effects in the theory of planned behavior: A study of consumer adoption intentions. International Journal of Research in Marketing, 12(2), 137156.

Taylor, S., \& Todd, P. (1997). Understanding the determinants of consumer composting behavior1. Journal of Applied Social Psychology, 27(7), 602-628.

Teng, P. K., Siong, H. K., \& Mesbahi, M. M. (2013). Awareness, recognition and intention: Insights from a non-Muslim consumer survey regarding halal-labeled food products in Malaysia. In $3^{\text {rd }}$ International conference on management proceeding, 1011. Hydro hotel, Penang, Mảaysia.

Vagias, W. M. (2006). Likert-type scale response anchors. Clemson International Institute for Tourism \& Research Development, Department of Parks, Recreation and Tourism Management. Clemson University. Clemson, South Carolina, USA.

Varinli, İ., Erdem, E., \& Avcllar, M. Y. (2016). Exploring the factors affecting purchase intention of halal certified foods in Turkey: A PLS-path modelling study. European Journal of Business and Management, 8(4), 68-78.

Yoh, E., Damhorst, M. L., Sapp, S., \& Laczniak, R. (2003). Consumer adoption of the internet: The case of apparel shopping. Psychology and Marketing, 20(12), 1095-1118. Yoo, K. S., \& Norton, M. (2007). Attitude toward internet web-sites, online information search and channel choices for purchasing. Journal of Fashion Marketing and Management, 11(4), 571-586.

Yunus, N. S. N. M., Rashid, W. E. W., Ariffin, N. M., \& Rashid, N. M. (2014). Muslim's Purchase Intention towards Non-Muslim's Halal Packaged Food Manufacturer. Procedia-Social and Behavioral Sciences, (130), 145-154. 
Zakaria, Z., Abdul Majid, M. D., Ahmad, Z., Jusoh, Z., \& Zakaria, N. Z. (2017). Influence of halal certification on customers' purchase intention. Journal Fundamentals Applications

Sciences, 9(5S), 772-787.

Zulariff, A. L., \& Mohamad, A. A. (2014). Food labels based on theory of planned behaviour in Klang Valley. Infrastructure University Kuala Lumpur Research Journal, 2(1), 113-118.

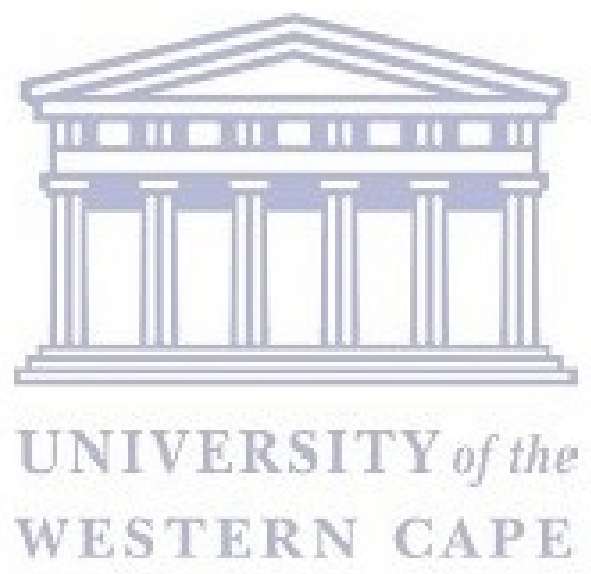

